\title{
The Prevalence of Street Begging in Nigeria and the Counseling Intervention Strategies
}

\author{
Osa-Edoh Gloria $^{1} \&$ Ayano Samuel ${ }^{2}$ \\ ${ }^{1}$ Department of Educational Psychology and Curriculum Studies, University Of Benin, Nigeria \\ ${ }^{2}$ Department of Vocational and technical studies, University Of Benin, Nigeria \\ Correspondence: Osa-Edoh Gloria, Department of Educational Psychology and Curriculum Studies, University \\ Of Benin, Nigeria. Tel: 234-80-2378-2859. E-mail: gloriaosaedoh@yahoo.com
}

Received: April 9, 2012 Accepted: June 5, 2012 Online Published: August 3, 2012

doi:10.5539/res.v4n4p77 URL: http://dx.doi.org/10.5539/res.v4n4p77

\begin{abstract}
This study investigated the causes and consequences of street begging in Nigeria. Descriptive survey design was adopted for the study. A sample of 52 adult beggars (26 male and 26 female) was selected through the purposive sampling technique for the study. Data were collected by means of an in depth structure interview designed by researchers. Simple percentages were used for analyzing the data the results showed that respondents indicated homelessness $(100 \%)$, poverty $(76.8 \%)$ and rejection by family harsh weather $(94.2 \%)$, as the worst consequence of begging. The study also revealed respondents' most important Economic/Psychosocial needs as Money (88.5\%), learning a trade (80.8\%), Healthcare (71.2\%) and Accommodation (55.7\%). Based on the findings, counseling intervention strategies were proffered in terms of organizing enlightenment workshops for stakeholders such as Government, Employment Agencies, News and Print Health care services as well as planning workshops for beggars and their families.
\end{abstract}

Keywords: street begging, causes, implications, possible solutions

\section{Introduction}

The growing incidence and influx of beggars in major cities in Nigeria as well as human carriage, kidnapping, indecent assault and a host of antisocial behaviour has assumed a worrisome dimension and break down of the family system. For instance, female beggars taking shelter under the bridges, parks and uncompleted buildings depend on serial male partners who exploit them sexually (Wikipedia free Encyclopedia, (2007). Street begging and homelessness are often regarded as anti-social behaviour issues by diverse stakeholder, including the media, politicians, traders, law enforcement officers and agencies, welfare and social service providers, the general public and people who beg (Lynch, 2005), To this end, a survey report indicated that beggars were victims of abuse, neglect and abandonment (GN/UNICEF, 1990).

According to Lynch (2005), an average of ten people is likely to beg daily. Carrous (cited in Qudiz, 2005:46) noted that an estimated 850 million people are hungry while 2 billion suffer from mineral or protein deficiencies. In view of this, it was projected that between now and the year 2030, there will be food-related tensions, with the most vulnerable countries being Near and Middle East, the Maghreb, the Nile Valley, West African and sub-Saharan Africa (Qudiz, 2005). In confirmation, Wolf (2005) reported that people, who beg, do so in order to meet subsistence needs; in addition, Qudiz (2005) revealed that $88 \%$ of respondents indicated adequate nutritional needs as their major reasons for begging as compared with need for accommodation (53\%), alcohol-dependency (41\%), health care $(29 \%)$ and drug dependency $(24 \%)$. He observed that none of the respondents begged because it was lucrative or easy money; the inference drawn from all these studies and many suggests that poverty is the main factor associated with street begging. All these and many more lend full support to evaluate the causes and consequences of street begging in Nigerian.

\section{The Nature of Street Begging}

In Europe, women from poorer countries like Bulgaria were engaged by organized 'gangs' to beg in cities (Wikipedia Free Encyclopedia 2007). The gangs usually collect the proceeds from them. Some beggars print illegitimate materials or posters related to church programmes or any charitable organization, which were found to be either disbanded or non-existent (Wikipedia Free Encyclopedia 2007). Experience has shown that this 
practice is common in Nigeria, where beggars use posters or envelopes with pictures of terminally ill people to solicit for money meant for their won personal use. Self-acclaimed healers of mental patients are fond of using them to beg for money from unsuspecting members of the public while their 'masters' watch from a hidden place.

\section{Causes of Street Begging}

Researchers have discovered that casual and consequential correlation exists between begging, homeless, poverty, and mental illness, inadequate access to housing, income, and health support services (Kennedy \& Fitzpatrick, 2001). Umoh (2000) opined that the effectiveness of any remedial action depends on tackling the casual factors. Some of the factors associated with begging are also follows:

Poverty: - Indication of poverty includes inadequate housing, poor health care, malnutrition, unemployment and lack of education. These were usually measured with regards to specific calories intake as well as earnings per capita (FGN/UNICEF, 1990). In survey from developed countries, it in was observed that a child living in a solo-mother family is five times as likely to live below the national poverty level, especially when both economic and parenting responsibilities fall on only 'one pair of shoulders; (UNICEF, 1996). In alleviating their sufferings 55\% of children were sent out as street workers in Nigeria, by their mothers (FGN/UNICEF, 1990).

Homelessness: - Aye (1996) quoting UNICEF report stressed that 100 million street children worldwide are homeless, and about 15,000 children in Nigeria alone are homeless. Literature also shown that $43 \%$ of beggars were long-term homeless, out of which $71 \%$ of them slept rough (Horn \& Cooke, 2001). Danczuk (2000) found that $80 \%$ of people who beg are homeless.

Break Down of the Family System: - Oluwole (cited in Aye, 1996) was of the view that most children ran away from their homes with complaints that their fathers' wives were too strict or that parents were too busy to care for them. Some forms of separation or divorce exert financial pressure on a partner and results into mothers sending their children out to beg on the streets (FGN/UNICEF, 1990).

Mental illness and Drugs:- in a study by Wolf (2005), some respondents attributed the reasons for begging to addictive disorders such alcohol dependency (41\%) and drug dependency (24\%) while most of the beggars spent money received from begging on irresponsible and unnecessary items, like drugs, alcohol and tobacco. Similarly, 45-47 respondents experienced drug dependency, 33-45\% experienced problematic alcohol use and $50 \%$ had a physical, intellectual or psychiatric disability (Danczuk, 2000; Jowette, Banks, \& Brown, 2001).

Unemployment: A survey of beggars showed that all the respondents were unemployed, with 82, being long-term unemployed (Lynch, 2005), in the Nigerian situation, FGN/UNICEF (1990) viewed street begging in terms of the economic situation of poor urban families, whereby children were subjected to working conditions, for the survival of the families involved.

Cultural and Religious Factors:- In Nigeria, begging seems to be a cultural practice especially among certain ethnic groups. For instance, it is common to see most nursing mothers who have twins begging for alms in the market places. They believe that children draw sympathy from passers-by who are moved with pity to give generously so as to help the mothers cater for them. Similarly, among the Indians, it is a traditional practice and a duty to give alms to beggars, especially the 'Sadhus', whose traditional way of life limits any income. They believe that even Shiva the Hindu god ran his household from begging alms (Wikipedia Free Encyclopedia, 2007).

In terms of religion, Hill (cited Abang 1986:86) opined that alms giving is regarded as one of the pillars of Islam, were by beggars are believed to bring blessings to others and in so doing, provides them with an opportunity for earning merit. Therefore, the wealthy give alms in fulfillment of religious obligation. In Nigeria, the 'Almajiral' system of education, which encourages children to move from place to place, contributes to destitution. According to Mijinyawa (2001), the Almajirai is a system of Qu' ranic education in Northern Nigeria, which existed before the 18th century jihad of Usman Danfodio. It was observed that the system is now a problem for being responsible for rural-urban migration (of children in particular), breeding touts and criminals as well as denying the potential leaders of tomorrow the opportunity of good life (Mijinyawa, 2001). The pilot study conducted by the National Council for the welfare of Destitute (NCWD) in 408 Almajirai schools in three towns in Kaduna State, revealed that there were over 30,000 Almajirais in these towns. This also noted that 21 million Nigerian children are out of school (Formal Education) as a result of destitution. Similarly Adefowokan (2007) observed that the 'Almajirinchi' refers to a practice of being an "Almajiri', whereby young boys study under Islamic clerics. The ultimate expectations for the boys leaving their families to be become Allah's servants and 
to gain support financially and materially from communities but unfortunately many of them end up in the streets, begging.

\section{Categories of Begging}

Relatively few researches have identified categories of begging across the continents of the world (burke, 1999, Horn \& Cooke, 2001). Three main classifications identified by them include the following:

Passive Begging: - This type involves a person either sitting or standing in one place with a sign or receptacle entreating donations. In their study, 8 respondents representing $(47 \%)$ engaged in passive begging (Horn \& Cooke, 2001).

Active Begging: - In this type, beggars move from pace to place with their receptacles soliciting money gifts. It was reported that 9 respondents representing (53\%) engaged in this form of begging (Horn \& Cooke, 2001).

Aggressive Begging:-This begging technique is one in which harsh words and intimidation is used in soliciting for help. Although this begging technique tends to be extremely low, it is said to be a 'self-defeating' begging strategy (Burke, 1999). This method is responsible for banning begging in Australia, England and Scotland. Burke (1999) was of the view that people who adopt passive begging style tend to obtain more donations than those who adopt the active style, while people who use aggressive styles were the least successful.

\section{Consequences of Street Begging}

A handful studies (Osofisan, 1996; Jowette, Banks, \& Brown, 2001; Lynch, 2005) have identified some consequences of begging. The finding suggests that apart form the strain that begging places on beggars factors impact negatively on their health and personality. Some of these include:

Explanation and sexual abuse: The dependency on public individuals by beggars has its dangers. Ones of such is that some of them have been identified as victims of HIV/AIDS (FGN/UNICEF), 1990). The chances of contracting AIDS and other Sexually Transmitted Diseases are much higher for this set of people. The implication is that those in this business and the rest of the population are at risk. Since woman and young girls are the most vulnerable, chances are that they end up with unplanned pregnancies, as seen in the case of most female beggars in Nigeria.

Kidnapping and Prostitution: Trafficking in woman and children in recent times is most distressing and inhuman, as a result of poverty. Many beggars in the streets risk being kidnapped and forced into the prostitution by individuals.

Crime and illegal drugs trade: In a previous research, an overwhelming $82 \%$ of respondents indicate that if they were unable to beg or prevented from doing so by law, they would resort to other illegal activities. (Horn \& Cooke, 2002). One of the commonest crime, which they were likely to be involved in, workshop lifting, indicated by $76 \%$ of respondents (Jowette, Banks, \& Brown, 2001). Unsuspecting beggars are likely victims of illegal drug trafficking, due to promises of better life by ring of traffickers.

Accident risks: Street begging could be risky to life especially in areas where there is heavy traffic. Beggars risk being run over by careless drivers. It is not unlikely that beggars constitute a great percentage of corpses occasionally on the highways in Nigeria.

Police harassment: In countries where begging has been banned, beggars risk imprisonment for a year, for first offenders or two years for a second or subsequent offence (lynch, 2005). Many are also victim's of police torture and brutality, particularly those who are tagged as 'rough sleeps' (Forell, McCarron, \& Schetzer, 2005).

The purpose of the study was to investigate the causes and consequences of street begging among adult beggars in Oyo town and also to assess their economic/psychosocial needs in order to identify its implications and proffer counseling intervention strategies.

\section{Method}

The study was a descriptive survey designed to elicit information on the causes and consequences of street begging in Nigeria. The population of study comprised all beggars in Oyo town.

Samples: The sample consisted of 52 adult beggars, made up 26 male and 26 female selected through the purposive sample technique from one major church and mosque where beggars were observed to converge in large numbers on Fridays and Sundays. However, because of the nature of begging adopted by some of them, only those seated at particular locations were recruited for the study. 
Instrument: The instrument of data collection was an in depth structured interview guide developed by researchers. The structure interview was written in English and consisted of these major questions, with several options. The three questions asked were as follows:

(1) What is the main reason for begging?

(2) As a beggar, what are the main hazards you are faced with?

(3) As beggar, what sort of help do you need most?

Respondents were required to indicate with 'Yes' or 'No'. Experts in guidance and counseling vetted the structured interview, after the trail interview, the language and structure of each interview statement revised.

Procedure for data collection: Two research assistants, fluent in Yoruba and Hausa were employed and trained for one week in interviewing techniques for the purpose of effective data collection aimed at eliminating language barrier since most of the beggars spoke either Yoruba or Hausa. The research team sought permission of the Imam and Pastor in charge of the mosque and church to allow the beggars converge for more interviews which was mainly for research purpose, aimed at improving their living conditions and they were assured of confidentially, Permission was sough for the interview to be tape recorded by the researchers. Each interview lasted for 45 minutes. At the end of the interviews, the researchers played back the tapes in their offices several times and the responses to each question were written.

Data analysis: simple percentages were employed in analyzing the data. The responses to an item was considered significant if over every percent of respondents indicated the 'Yes' pattern of response while responses below fifty parent were insignificant.

\section{Result}

Table 1-3 presents the simple result on causes, consequences and economic/psychosocial needs of beggars.

Table 1. Showing percentage scores of male and female respondents on the causes of street begging $(\mathrm{N}=52)$

\begin{tabular}{llcccc}
\hline & & \multicolumn{3}{c}{ Mole $(\mathrm{N}=26)$} & Yesponse categories \\
No & Item & Yes & No & Yes & No \\
\hline 1 & Poverty & 30.8 & 19.2 & 46.2 & 3.8 \\
2 & Homelessness & 50.0 & 0.0 & 50.0 & 0.0 \\
3 & Unemployment & 50.0 & 0.0 & 50.0 & 0.0 \\
4 & Religious obligation & 34.6 & 15.4 & 28.8 & 21.2 \\
5 & Children's education & 9.6 & 40.4 & 34.6 & 15.4 \\
6 & Treating sickness & 26.9 & 23.1 & 13.5 & 36.5 \\
7 & Family rejection & 28.8 & 21.2 & 0.0 & 50.0 \\
\hline
\end{tabular}

Note: Final percentage are sums of 'Yes' responses by male and female respondents

Table 1 shows that out of eight causes of begging such as poverty, Homelessness, Unemployment, Religious Obligation, Education for Children, Sickness, Rejection by family and Money to hard drugs, only for were significant. These include Homelessness (100\%), Unemployment (100\%), Poverty (76.8\%) and Rejection by Family $71.1 \%$. The insignificant causes of begging indicated by the respondents were education for children (44.2\%), Sickness (40.4\%) and Money to buy Hard Drugs (6.2\%)

Table 2. Showing percentage scores of male and female respondents on the consequences of street begging $(\mathrm{N}=52)$

\begin{tabular}{llcccc}
\hline & & \multicolumn{4}{c}{ \% response categories } \\
& & \multicolumn{2}{c}{ Male $(\mathrm{N}=26)$} & Female $(\mathrm{N}=26)$ & No \\
\hline No & Item & Yes & No & 32.7 & 17.3 \\
2 & Sexual exploitation & 3.8 & 46.2 & 5.8 & 44.2 \\
3 & Ridnapping & 15.4 & 34.6 & 21.2 & 28.8 \\
4 & Physical assault & 7.7 & 42.3 & 11.5 & 38.5 \\
5 & Forced prostitution & 36.5 & 13.5 & 26.9 & 23.1 \\
6 & Forced into crime & 0.0 & 50.0 & 0.0 & 50.0 \\
7 & Harsh weather & 0.0 & 50.0 & 50.0 & 0.0 \\
\hline
\end{tabular}


Table 2. Showing that the various consequences of begging such as sexual exploitation, kidnapping, Road accident, physical assault, prostitution, and Crime and Harsh weather resulting in illness, majority of respondents indicate harsh weather $(94.2 \%)$ as a consequence of begging. The insignificant of begging by the respondents were sexual exploitation (36.5\%), road accident (28.9), and Prostitution (26.9\%), Kidnapping (21.2\%) and Crime $(0.0 \%)$

Table 3. Showing percentage scores of male and female respondents on the economic/psychosocial needs

\begin{tabular}{llcccc}
\hline & & \multicolumn{3}{c}{ M response categories } \\
No & Item & Yes & No & Yes & No \\
\hline 1 & Accommodation & 19.28 & 30.8 & 36.5 & 13.5 \\
2 & Money & 38.5 & 11.5 & 50.0 & 0.0 \\
3 & Employment & 9.6 & 40.4 & 21.2 & 28.8 \\
4 & Learn a trade & 42.3 & 7.7 & 38.5 & 11.5 \\
5 & Health care & 32.7 & 17.3 & 38.5 & 11.5 \\
6 & Children's education & 9.6 & 40.4 & 34.6 & 15.4 \\
\hline
\end{tabular}

Table 3 shows that in terms of Economic/Psychosocial needs, positive responses were indicated in the following areas-Money (88.8\%), Learning a trade (80\%.8\%), Healthcare $(71.2 \%)$ and Accommodation $(55.7 \%)$. However, the respondents were negative in terms of Education for children (44.2\%) and employment (30.8\%)

\section{Discussion of Findings}

The finding of study, indicating respondents' main reason for begging as Homelessness (100\%), Unemployment $(100 \%)$, Poverty (76.8) and Family rejection $(71.1 \%)$ are in line with earlier researches, which suggest that these factors have been strongly and consistently associated with begging in both developed and developing countries of the world (Aye, 1996; UNICEF, 1996; Kennedy \& Fitzpatrick, 2001; Lynch, 2005). Of the four causes of begging indicated by the respondent, poverty and homelessness in particular are covariates frequently associated with begging. This observation is an evidence of the impact that these factors have in the lives of not only beggars, but also the entire populace. In support of this, Adaramaja and Adegbite (2005) reiterated that these factors are used in judging the worth and potentials the support and maintenance provided by a country's social system.

The study revealed that in terms of the consequences of begging, the most significant was harsh weather causing sickness (94.2\%). This means that most male and female respondents perceived this factor as distressing. Obviously, adverse weather conditions are unfavorable and associated with airborne diseases, including flu, cough, and catarrh, only to mention a few. In agreement, Adaramaja and Adegbite (2005) were of the view that unhealthy lifestyles or behaviour might have direct or indirect consequences in the health and well being of individual causing restlessness, accidents, and untimely deaths among others. Similarly, result is consistent with the findings of FGN/UNICE (1990), that exhaustion and exposure to harsh weather was one of the biggest challenges of street children workers in Nigeria. Finally, the study revealed the most important economic psychosocial needs of the respondents as Money (88.5\%), learning a trade $(80.5 \%)$ Healthcare $(71.2 \%)$, and Accommodation (55.7\%). These factors remain important predictors of good living and are germane to human existence. FGN/UNICEF (1990) noted that these were necessary for beggars who were observed to have suffered abuse neglect and abandonment in the society.

\section{Counseling Implications}

The most effective approach to solving the issue to street begging is through counseling. It is a process of helping clients to engage in better choices. In this regard, begging is a maladaptive behaviour in which counseling can help beggars change modifies the way they think, act and feel. One of the strategies that counselors can use in this intervention is the Rational Emotive Therapy. This approach will enable beggars to change their illogical mode of reasoning and boost their image and self concept so that they in turn will find reason to believe in themselves and in their abilities to work and fend for themselves instead of begging alms. Counseling can also help beggars to be assertive and in the process become assets instead of liabilities to their 
families and society. In this case, counselors can apply their skills in vocational, educational-social counseling will enable beggars to explore alternative ways off utilizing their acquired skills.

\section{Recommendation}

Street begging deserves a collaboration of the efforts of the government, Nigerian populace, counselors, and NGOs in order to fight poverty and proving mass education via the news and print media. The measures adopted by foreign countries for checking street begging menace such as Zero Tolerance, Police Training and Referral, Assertive Outreach and Social Service Intervention etc, are to be used with caution as Waldron (2000)argued that zero policing approach to begging would result in short-term decrease in the incidence of begging. The method of designed by foreign researchers may not be ideal for Nigeria due to its peculiar culture and values which are quite distinct form those o the western world. The following measures are necessary in eradicating street begging in Nigeria:

Programmes in form of workshops and seminars can be taken to churches and mosques, for educating parents on the need to nurture their families. They should also encourage them to be each other's keeper, a cherished African way of helping those in need, which is, reviving the family system as well as discouraging cultural and religious beliefs about begging. The workshop can be planned for beggars in all states intimating them on the need to be off the streets, inviting resource persons to teach various trades and liaising with Federal, State and Local Government to provide funds for a take off projects such as shoe making, weaving, soap making etc.

There should be a special department for the destitute in the Ministry of Social Welfare, Funded by Government in order to organize and manage rehabilitation centers in all the states. Government should discourage begging by allocating certain percentage as monthly allowance to beggars as well as instruct employment agencies to reserve certain percentage of their work force for them. A rehabilitation center should perform three main functions such as physical restoration, educational rehabilitation and psychosocial rehabilitation.

The Federal Government should invite all stakeholders to a meeting in order for them to suggest ways of helping in form of contributing funds to assist the less privileged in terms of provision of health care, accommodation and employment.

The news and print media should collaborate by campaigning for wealthy Nigerians to build low cost houses and provide employment for the destitute, especially those who believe in almsgiving as an obligation. There is need for an awareness campaign on change of attitude towards the poor.

\section{Conclusion}

This study as identified that street begging is associated with such causal factors as homelessness, poverty, unemployment and family rejection of beggars. Evidence also shows that researchers are seeking lasting ways of reducing the incidence of begging. Since measures such as zero policing, referral interventions have yielded little, a more dynamic approach is necessary. Also, since literature ahs identified that most of the people who beg were children ad young people, it implies that the nation is loosing the economic contributions of such people, in Nigeria as well as jeopardizing the lives of children. The solution does not lie with Government alone. Counseling should focus on the family first, whose main tasks of care, love and provision of basic necessities of life have been relegated as a result of urbanization, separation and divorces. Family counseling clinics should be challenged in this area by discouraging families from engaging young children in street begging, helping to changing their attitude, and making them realize the dangers inherent in street begging which includes accident risk, sexual, exploitation and crime.

\section{References}

Abang, T. B. (1986). Rehabilitating the disable and destitute in Nigeria. Retrospect and Prospects. Nigeria Journal of counseling and development.

Adaramaja, S. H., \& Adegbite, C. O. (2005). Relationship Between Lifestyles and Health Problems suffered by People of Kaduna State. Journal of Health, Physical Education and Recreation, 4, 107-108.

Adefowokan, D. (2007, June 17). Katsina: A glimpse of Yar'Adua's Home town. The Sunday sun, 3(222), 28-29.

Adegbite, C. O. (2005). Disabilities in Children: a Perspective. Journal of Health Physical Education and Recreation, 4, 92.

Aye, E. U. (1996). Containing Street Children Menace: In Woman in Numerical News, 1996/97 (Ed). Federal Office of Statistics Publication, 70, Lagos, Nigeria. 
Burke, R. J. (1999). Tolerance or Intolerance? The Policing of Begging in the Urban Context? In H. Dean (Ed), Begging Questions: Street-level Economic Activity and Social Policy Failure (pp. 219-230).

Daczuk, S. (2000). Walk on by Begging, Street, Drinking and the Giving Age. In p. Lynch (Ed), Critique and Comment; Understanding and Responding to Begging (p. 18). Australian Journals.

Dean, H. (1990). Begging Questions: Street-Level Economic Activity and Policy Failure (p. 163).

Dean, H., \& Gale, K. (1999). Begging and the Contradictions of Citizenship. In H. Dean (Ed), Begging Question: Street-Level Economic Activity and Social Policy Failure (vol. 3, p.14).

FGN/UNICEF. (1990). Street Children in the Cities of Kaduna and Calabar: Children and Woman in Nigeria. $A$ situation Analysis, 48.

Forell, S., McCarron, E., \& Schetzer, L. (2005). No Home, no Justice?. The Legal Needs of Homeless People in NSW. Retrieved May 14, 2007, from http://www.lawfoundation.net.au/access/homeless/nohomenjustice.pdf

Horn, M., \& Cooke, M. (2001). A question of Begging: a Study of the Extent and Nature of Begging in the city of Melbourne. In P. Lynch (ed.), Critique and Comment: understanding and responding to begging. Australian journals.

Horn, M., \& Cooke, M. (2002). Understanding Begging in our Public Spaces'. Parity, 15(1), 10.

Jowett, S., Banks, G., \& Brown, A. (2001). Looking for Change: the Role and Impact of Begging on the Lives of People who Beg. In P. Lynch (ed.), Australian Journals.

Kennedy, C., \& Fitzpatrick, S. (2001). The links between begging and Rough Sleeping: A Question of Legitimacy?. Housing Studies, 16, 549-560.

Lynch, P. (2005). Critique and Comment: Understanding and Responding to Begging. Australian Journals, 16.

Mijinyawa, A. L. (2001, April 16). What to do with Almajiral. New Nigerian Newspaper, 14, Lagos.

Oluwole, S. (1996). Containing Street Children Menace. Women Numerical News, 1996/97 (Ed). Federal Officer of Statistics, 70, Lagos.

Osofisan, O. (1996). A Crime Against the Child'. In Women in Numerical News, 1996/97 (Ed). Federal Office of Statistics, 26, Lagos.

Quidz, B. (2005). Poverty and hunger: a race against the clock. The International French News Magazine: Label, $57,45-46$.

Umoh, S. H. (2000). Managing the problems of the Nigerian Adolescents through Counseling. A paper Presented at a Workshop Organized by the Federal Polytechnic, Offa, Nigeria.

UNICEF. (1996). National Performance Gap. The Progress of Nations (pp. 33-34).

Waldron, J. (2000). Homelessness and Community. University of Toronto law Journal, 50, 371-387.

Wikipedia Free Encyclopedia. (2007). Begging. Retrieved May 14, 2007, from http://en.wikipidia.org/wiki/begging.htm

Wolf, M. (2005). Assisting Homeless People: the need to improve their access to Accommodation and Support Services. Party, 18(1), 25-26. 